\title{
Chemical changes of kradi cheese stored at refrigeration temperature under vacuum and normal conditions
}

\author{
Hilal Ahmad Punoo
}

Received: 08 July 2019 / Accepted: 28 December 2019 / Published online: 27 February 2020

(C) Indian Dairy Association (India) 2020

\begin{abstract}
This study investigated changes in chemical properties of kradi cheese stored under vacuum and normal conditions at $5^{\circ} \mathrm{C}$ at weekly intervals for a period of fourteen weeks. The initial moisture content of $49.09 \%$ in normal packed samples decreased to $48.34 \%$ while in vacuum packed samples it decreased to $48.31 \%$ at $14^{\text {th }}$ week of storage. The drop in initial $\mathrm{pH}$ was small in both vacuum packed and normal packed samples. The decrease in acidity was small in vacuum packed samples than normal packed samples. Fat leakage was less under vacuum packaging. The initial free fatty acid content of $0.93 \mathrm{meq} / \mathrm{g}$ in normal packed samples increased to $17.9 \mathrm{meq} / \mathrm{g}$ while in vacuum packed samples it increased to $21.31 \mathrm{meq} / \mathrm{g}$ on $14^{\text {th }}$ week of storage. The initial tyrosine value of $0.013 \mu \mathrm{g} 5 \mathrm{ml}^{-1}$ in normal packed samples increased to $5.25 \mu \mathrm{g} 5 \mathrm{ml}^{-1}$ while in vacuum packed

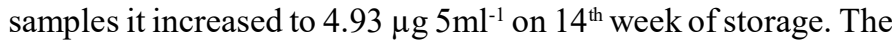
vacuum packaging retarded increase in acidity in comparison to normal packaging.
\end{abstract}

Keywords: Free fatty acids, Kradi cheese, Moisture loss, Refrigerated storage, Tyrosine value, Vacuum packaging

\section{Introduction}

Kradi, semisoft, white, unripened fresh cheese (Punoo et al. 2018a, $2018 \mathrm{~b}$ and 2018c) is a famous traditional milk product of Jammu and Kashmir, India manufactured primarily by the tribal population

Hilal Ahmad Punoo ( $\square)$

Department of Food Science \& Technology,

University of Kashmir, India

Email:hilal_punoo@rediff.com of Gujjar and Bakarwal community. It is sold unpackaged, undergoes moisture loss and increase in acidity. Despite this, due to increased demand for this cheese, the demand for modern packaging is increasing at production units. The annual production is 21 thousand kilogram during 2017 and sales of product has increased by $15 \%$ in $2016-17$. Although the sale of kradi cheese is increasing annually but no studies has been reported with respect to chemical changes during storage. The study of chemical changes in this product is necessary from food safety point of view for clearing the concerns of consumers.

During storage of cheese biochemical changes involve proteolysis and lipolysis mainly by rennet enzymes or bacteria (Fox and Mc Sweeney, 2004). The chemical degradation of cheese is not desired during storage. Lipolysis involves accumulation of free fatty acids (FFA) with most of the FFA being released from triglycerides.

Vacuum Packaging has developed much attention in production of dairy products for keeping safe from harm, prolonging the shelf life, retarding the activity of bacteria and reducing the use of preservatives. Descriptive sensory analysis, physico chemical, microbiological, textural and microstructural properties of kradi cheese have been reported (Punoo, et al. 2018c, Punoo, et al. 2018a; Punoo, et al. 2018b).

As compared to normal packaging, vacuum packaging can reduce chemical deterioration. The alteration in packaging condition by vacuum can either accelerate or inhibit the biochemical changes during storage of kradi cheese. Thus vacuum packaging can be a way of preserving the chemical quality of kradi cheese. Therefore present study was aimed at assessment of chemical changes of kradi cheese throughout its storage at different periods at refrigeration temperature under vacuum and normal packaging conditions.

\section{Materials and Methods}

\section{Preparation of Kradi cheese}

Kradi cheese was made as per the method described (Punoo et al. 2018a). The fresh product was packed in multilayer laminates (5-layer natural PFP, 20x20 cm size and 105-175 micron thickness 
of film) under vacuum and normal packaging conditions and stored at refrigeration temperature $\left(5 \pm 1^{\circ} \mathrm{C}\right)$. The products stored were evaluated at weekly intervals to monitor changes in various chemical properties for a period of fourteen weeks.

\section{Chemical analysis}

\section{Moisture}

The moisture content in kradi cheese was analyzed by the method as described in IS: SP: 18 (Part XI) 1981.

\section{Titratable acidity}

Titratable acidity of kradi cheese was determined by the method recommended by the Association of Official Analytical Chemists (AOAC, 1984).

\section{pH}

Ten $\mathrm{g}$ of the grated sample was mixed with $10 \mathrm{ml}$ of glass distilled water and slurry was prepared thereof in a mortar. The $\mathrm{pH}$ of slurry was determined by using double junction electrode $\mathrm{pH}$ Scan 2+, Eutech Instrument Pvt. Ltd., Singapore.

\section{Fat leakage}

Fat leakage of kradi cheese samples was determined by the method of Nilson and La Clair (1976).

\section{Free fatty acids (FFA)}

The total free fatty acids content of the kradi cheese was estimated by the method delineated by Deeth and Fitz-Gerald (1976).

\section{Tyrosine value}

The tyrosine content as a measure of proteolysis in Kradi was calorimetrically determined according to the method of Hull (1947). Five grams of sample were weighed and taken in a clean dry test tube, added with $10 \mathrm{ml}$ of distilled water followed by addition of $10 \mathrm{ml}$ of $0.72 \mathrm{~N}$ TCA. The test tubes were then stoppered shaken vigorously and incubated at $27^{\circ} \mathrm{C}$ for $10 \mathrm{~min}$. The precipitated proteins were filtered through Whatman No. 42 filter paper and the tyrosine content in the filtrate was determined calorimetrically. To $5.0 \mathrm{ml}$ of this TCA soluble filtrate, $2.0 \mathrm{ml}$ of distilled water, 10 $\mathrm{ml}$ of sodium carbonate reagent $\left(75.0 \mathrm{~g}\right.$ anhydrous $\mathrm{Na}_{2} \mathrm{CO}_{2}$ and $10.0 \mathrm{~g}$ sodium tetra phosphate dissolved in glass distilled water and diluted to $500 \mathrm{ml}$ ) followed by $2.0 \mathrm{ml}$ of the Folin's phenol reagent (Folin's phenol reagent diluted 1: 2 with distilled water) was added, mixed well and incubated again at $27^{\circ} \mathrm{C}$ for $10 \mathrm{~min}$ for colour development. This solution was used as a blank. The intensity of blue colour so developed was measured at $650 \mathrm{~nm}$ using UV visible spectrophotometer. A tyrosine standard curve was prepared using concentrations of 0,10 , up to $100 \mu \mathrm{g} / 5 \mathrm{ml}$ in
TCA filtrate. A regression equation was obtained using the absorbance of the standard solutions against their tyrosine concentration ( $\mu \mathrm{g} 5 \mathrm{ml}^{-1}$ ). The tyrosine equivalent in Kradibased on its concentration in the final $5 \mathrm{ml}$ TCA soluble filtrate obtained from $5 \mathrm{~g}$ sample used for producing blue colour was expressed in terms of tyrosine equivalent (mg $100 \mathrm{ml}^{-1}$ ).

\section{Statistical analysis}

The data obtained during the present investigation was compared by one-way analysis of variance (ANOVA) with the application of SYSTAT software, version 6.0.1 copyright (C) 1996, SPSS INC. Significant difference $(\mathrm{p}<0.05)$ among treatments were detected using Duncan's multiple range tests.

\section{Results and Discussion}

The loss of moisture during storage is a common observation for cheeses. Level of moisture in the product plays a significant role on quality of the product during storage as far as bacterial activity, browning reaction and the acceptability of kradi is concerned. Therefore, packaging materials and packaging techniques are carefully selected to check the moisture loss during storage. The initial moisture content of $49.09 \%$ in air packed kradi samples (Table 1) decreased to $48.34 \%$ while in vacuum packed samples it decreased to $48.31 \%$ on $14^{\text {th }}$ week of storage. There was more loss of moisture under normal packaging conditions compared to vacuum conditions in saloio cheese stored at $8^{\circ} \mathrm{C}$ for 60 days (Pantaleao et al. 2007). Both packaging conditions and storage periods had no significant effect on the moisture content of kradi samples stored at $5^{\circ} \mathrm{C}$ (Table 2). The initial $\mathrm{pH}$ of 5.4 in normal packed kradi samples dropped to 4.82 while in vacuum packed samples it dropped to 4.80 on $14^{\text {th }}$ week at $5^{\circ} \mathrm{C}$ of storage temperature. The effect of packaging conditions and the effect of storage periods was non significant on $\mathrm{pH}$ of samples (Table 2). Fuentes, L. et al. 2015, reported significant decrease in $\mathrm{pH}$ of pasta filata mexican cheese during refrigerated vacuum storage for 24 days. The initial acidity of $0.54 \%$ lactic acid (LA) in normal packed samples increased to $1.14 \% \mathrm{LA}$ on $14^{\text {th }}$ week of storage while in vacuum packed samples it increased to $1.05 \%$ LA. The higher development of acidity under normal packaging conditions could be attributed to increased activity of lactic acid bacteria under normal compared to vacuum conditions. The effect of packaging conditions and storage periods was highly significant (pd"0.01) on the acidity of samples (Table 2). Since vacuum packaging did not favoured increase in acidity of Kradi cheese, therefore vacuum packaging can be more desirable from consumers point of view as the sourness in kradi cheese because of acidity development will be less. A slower increase in acidity for white cheese under vacuum compared to normal conditions stored at $4-5^{\circ} \mathrm{C}$ for 90 days was reported (Cinbas and Kilic, 2006). Free-oil formation, also called 'oiling off' or 'fat leakage' is the tendency of liquid fat to separate from melted cheese and accumulate in pockets or pools, particularly at the surface of 
cheese. The excessive free oil and limited free oil are considered serious defects in cheese. Table 1, depict the trend and values for fat leakage of kradi packed in two types of atmospheres (vacuum and normal) and stored at $5^{\circ} \mathrm{C}$ for fourteen week period. At $5^{\circ} \mathrm{C}$ of storage temperature, the initial fat leakage of $0.16\left(\mathrm{~cm}^{2}\right)$, in normal packed samples increased to $0.81\left(\mathrm{~cm}^{2}\right)$ after $14^{\text {th }}$ week of storage while in vacuum packed samples it increased to 0.71 $\left(\mathrm{cm}^{2}\right)$. Similar observations were also recorded by Kindstedt and Rippe (1988) who observed that refrigerated storage of mozzarella cheese increased the amount of free oil. Gobbetti et al. 2002, reported an increase in flowability during 60 days ripening of caciocavllo pugilese cheese. ANOVA (Table 2) revealed that both packages as well as storage periods had no significant effect on the fat leakage of samples stored at $5^{\circ} \mathrm{C}$. Slower fat leakage under vacuum packaging is good for storage of product. The initial FFA of $0.93 \mathrm{meq} / \mathrm{g}$ in air packed kradi samples increased to 17.9 $\mathrm{meq} / \mathrm{g}$ on $14^{\text {th }}$ week of storage while in vacuum packed samples it increased to $21.31 \mathrm{meq} / \mathrm{g}$. The slower rate of lipolysis at $5^{\circ} \mathrm{C}$ indicates that rate of lipolysis was slower under refrigeration conditions. A slower rate of lipolysis for white cheese under vacuum compared to normal conditions stored at $4-5^{\circ} \mathrm{C}$ for 90 days was reported (Cinbas \& Kilic., 2006). Ahuja and Goyal (2013) reported that increase in concentrations of free fatty acids (FFA) of vacuum packed paneer tikka samples during refrigerated vacuum storage for a period of 30 days and observed influence of storage intervals on the FFA values was more significant $(\tilde{\mathrm{n}}<0.01)$ than types of packages $(\tilde{\mathrm{n}}<0.05)$ during storage. Fuentes et al. 2015, reported that concentrations of free fatty acids (FFA) did not change $(\mathrm{P}>0.05)$ in pasta filata mexican cheese during refrigerated vacuum storage for 24 days. The camembert cheese manufactured using tibetan kefir co-culture underwent lipolysis (Mei et al. 2015). The packages and storage periods had no

Table 1 Effect of vacuum packaging on chemical characteristics ${ }^{1}$ of $k r a d i$ cheese stored at $5 \pm 1^{\circ} \mathrm{C}$

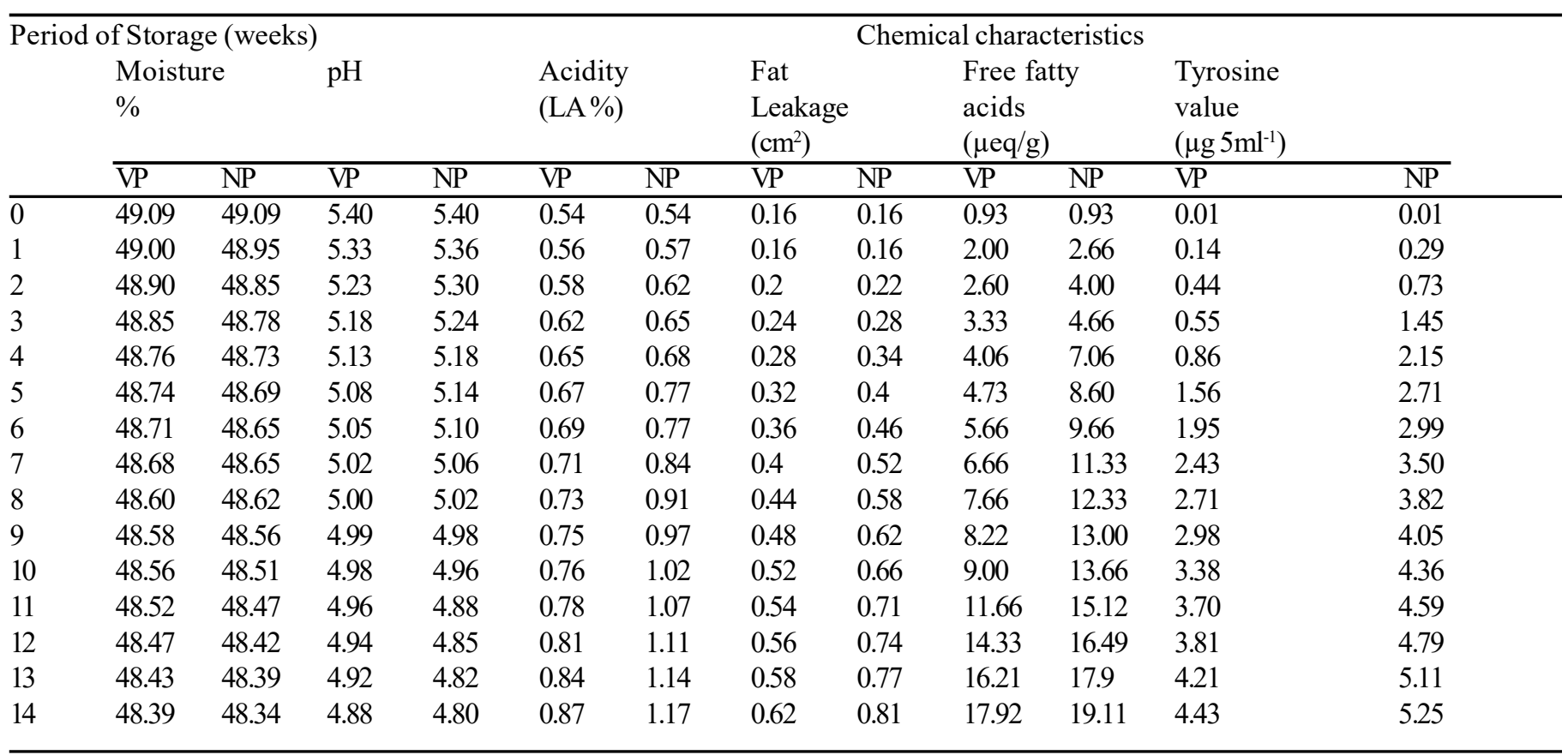

${ }^{1}$ Values are mean of three trials $\mathrm{NP}=$ Normal packaging

$\mathrm{VP}=$ Vacuum pack

Table 2 Analysis of variance for chemical characteristics of $k$ radi cheese stored at $5 \pm 1^{\circ} \mathrm{C}$

\begin{tabular}{|c|c|c|c|c|}
\hline \multirow[t]{2}{*}{ Attributes } & \multirow[t]{2}{*}{$\begin{array}{l}\text { df ( between } \\
\text { packaging system) }\end{array}$} & \multicolumn{2}{|l|}{$\begin{array}{l}\text { Mean sum of } \\
\text { squares }\end{array}$} & \multirow[t]{2}{*}{ F-value } \\
\hline & & Packaging System & Time interval & \\
\hline Moisture \% & 1 & $0.01^{\mathrm{ns}}$ & $0.04^{\mathrm{ns}}$ & 0.25 \\
\hline $\mathrm{pH}$ & 1 & $-1.11 \times 10^{-16 \mathrm{~ns}}$ & $0.03^{\mathrm{ns}}$ & $-3.6 \times 10^{-15}$ \\
\hline Acidity \% & 1 & $0.16^{* *}$ & $0.02 * *$ & 5.59 \\
\hline Fat leakage & 1 & $0.08^{\mathrm{ns}}$ & $0.03^{\mathrm{ns}}$ & 2.16 \\
\hline
\end{tabular}

** Significant at $1 \%, *$ Significant at $5 \%$, ns Non-significant 
significant effect on the FFA of kradi samples (Table 2). The initial tyrosine value of $0.013 \mu \mathrm{g} 5 \mathrm{ml}^{-1}$ in air packed $k \mathrm{radi}$ samples

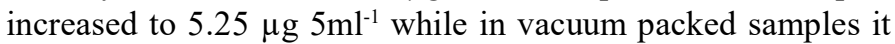
increased to $4.93 \mu \mathrm{g} 5 \mathrm{ml}^{-1}$ on $14^{\text {th }}$ week of storage. The slower rate of proteolysis at $5^{\circ} \mathrm{C}$ indicates that proteolytic enzymes were less active under refrigeration conditions. Slower rate of proteolysis was reported for white cheese (Turkish cheese) under vacuum compared to non-vacuum conditions stored at $4-5^{\circ} \mathrm{C}$ for 90 days (Cinbas and Kilic, 2006). Ahuja and Goyal (2013) reported that increase in concentrations of tyrosine content of vacuum packed paneer tikka samples during refrigerated vacuum storage for a period of 30 days and observed duration of storage as well as type of package significantly affected tyrosine content. Fuentes et al. 2015, reported that proteolysis did not showed significant changes during storage in pasta filata mexican cheese during refrigerated vacuum storage for 24 days. The camembert cheese manufactured using tibetan kefir co-culture underwent proteolysis (Mei et al. 2015). The effect of packaging conditions and storage periods was non significant on the tyrosine value of kradi samples (Table 2). The chemical analysis was discontinued after14 weeks of storage under normal packaging and vacuum packaging as the samples expired due to off flavor development.

\section{Conclusions}

This study revealed that vacuum packaging of kradi cheese prevented loss of moisture, drop in $\mathrm{pH}$ was low and increase in acidity was also slow besides a lesser fat leakage. Proteolysis and lipolysis were slowed down by vacuum packaging. The increase in acidity of product was retarded under vacuum packaging which is a very good characteristic from consumer's point of view. Chemical quality of product was better maintained at refrigeration temperature of $5^{\circ} \mathrm{C}$. This study also reveals that although chemical changes occurred both under normal and vacuum packaging, but the magnitude of changes under vacuum packaging was less. This study supports that both normal and vacuum packaging are desirable for packaging of kradi cheese. However from a technological point of view, vacuum packaging could be an alternative to conventional packaging for fresh $\mathrm{kradi}$ cheese production designed for long storage. Therefore vacuum packaging of kradi cheese can extend the shelf life of this traditional regional product and can guarantee the consumers a quality product.

\section{Acknowledgements}

This research work was carried out at Dairy Technology Division, National Dairy Research Institute Karnal. Therefore, author is thankful to National Dairy Research Institute Karnal for carrying out this research work.

\section{References}

Ahuja KK, Goyal GK (2013) Combined effect of vacuum packaging and refrigerated storage on the chemical quality of paneer tikka. J Food Sci Technol 50: 620-623

AOAC (1984) Official Methods of Analysis, Association of Analytical Chemists, 15th Ed. Association of Official Analytical Chemist,nc., Washington, DC.

Cinbas T, Kilic M (2006) Proteolysis and lipolysis in white cheeses manufactured by two different production methods. Int J Food Sci Technol 41: 530-537

Deeth HC, Fitz-gerald CH (1976) Lipolysis in Dairy Products. Netherlands J Dairy Technol 43: 73-76

Fox PF, McSweeney PLH (2004) Cheese: An Overview. In P. F. Fox, P. L. H McSweeney, T M. Cogan, \& T. Guinee (Eds.), Cheese: Chemistry, physics and microbiology. Vol.1.General aspects (pp.1-18). Oxford: Elsivier.

Fuentes L, Mateo J, Quinto EJ, Caro I (2015) Changes in quality of nonaged pasta filata Mexican cheese during refrigerated vacuum storage. J Dairy Sci 98: 2833-2742

Gobbetti M, Morea M, Baruzzi F, Corbo MR, Matarrante A, Considine T, Cagno DR, Guinee T, Fox PF (2002) Microbiological compositional biochemical and textural characterization of caciocavallo pugliese cheese during ripening. Int Dairy J 12: 511-523

Hull ME (1947) Studies on milk proteins II. Colorimetric determination of Partial hydrolysis of the proteins in milk. J Dairy Sci 30: 81-85

IS: SP 18 (Part XI) (1981) Hand book of Food analysis. Part XI, Dairy Products. Bureau of Indian Standards, Manak Bhavan, New Delhi.

Kindstedt P S, Rippe J K (1988). Rheological and proteolytic changes in Mozzarella cheese during refrigerated storage. J Dairy Sci 71: 70-75

Mei J, Guo Q, Wu Y, Li Y, Yu H (2015) Study of Proteolysis, Lipolysis, and Volatile compounds of a camembert type cheese manufactured using a freeze dried Tibetan Kefir co-culture during ripening. Food Sci Biotechnol 24: 393-402

Nilson KM, Laclair FA (1976) A national survey of the quality of Mozzarella cheese. Am Dairy Rev 38: 18

Pantaleao I, Pintado MME, Pocas MFF (2007) Evaluation of two packaging systems for regional cheese. Food Chem 102: 481-487

Punoo HA, Patil GR, Singh RRB (2018a) Textural and microstructural properties of Kradi cheese (an indigenous cheese of Jammu and Kashmir, India). Int J Dairy Technol 71: 372-381

Punoo H A, Patil GR, Singh RRB (2018b) Physico-chemical and microbiological composition of Kradi cheese. Indian J Dairy Sci 71: 152-155

Punoo HA, Patil GR, Singh RRB (2018c) Quantitative descriptive sensory analysis of Kradi Cheese. SKUAST J Res 20: 230-237 